\title{
Three years of trace gas observations over the EuroSiberian domain derived from aircraft sampling - a concerted action
}

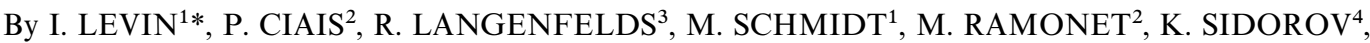 \\ N. TCHEBAKOVA 5 , M. GLOOR ${ }^{6}$, M. HEIMANN ${ }^{6}$, E.-D. SCHULZE ${ }^{6}$, N. N. VYGODSKAYA ${ }^{4}$, \\ O. SHIBISTOVA ${ }^{5}$ and J. LLOYD ${ }^{6}$, ${ }^{1}$ Institut für Umweltphysik, Universität Heidelberg (UHEI-IUP), \\ Im Neuenheimer Feld 229, 69120 Heidelberg, Germany; ${ }^{2}$ Laboratoire des Sciences du Climat et de \\ l'Environnement (LSCE), CE Saclay, Orme des Merisiers, Bât. 709, 91191 Gif-sur-Yvette Cedex, France; \\ ${ }^{3}$ CSIRO Atmospheric Research (CAR), Private Bag 1, Aspendale, Victoria 3195, Australia; ${ }^{4}$ Svertsov \\ Institute for Evolutionary and Ecological Problems (IPEE), Leninskii pr. 33, 117071 Moscow, Russia; \\ ${ }_{5}^{5}$ Institute of Forest, Siberian Branch, Russian Academy of Sciences (IF SB RAS), Akademgorodok, 660036 \\ Krasnoyarsk, Russia; ${ }^{6}$ Max-Planck-Institut für Biogeochemie (MPI-BGC), Postfach 100 164, 07701 Jena, \\ Germany
}

(Manuscript received 2 July 2001; in final form 22 April 2002)

\begin{abstract}
A three-year trace gas climatology of $\mathrm{CO}_{2}$ and its stable isotopic ratios, as well as $\mathrm{CH}_{4}, \mathrm{~N}_{2} \mathrm{O}$ and $\mathrm{SF}_{6}$, derived from regular vertical aircraft sampling over the Eurasian continent is presented. The four sampling sites range from about $1^{\circ} \mathrm{E}$ to $89^{\circ} \mathrm{E}$ in the latitude belt from $48^{\circ} \mathrm{N}$ to $62^{\circ} \mathrm{N}$. The most prominent features of the $\mathrm{CO}_{2}$ observations are an increase of the seasonal cycle amplitudes of $\mathrm{CO}_{2}$ and $\delta^{13} \mathrm{C}-\mathrm{CO}_{2}$ in the free troposphere (at $3000 \mathrm{~m}$ a.s.l.) by more than $60 \%$ from Western Europe to Western and Central Siberia. $\delta^{18} \mathrm{O}-\mathrm{CO}_{2}$ shows an even larger increase of the seasonal cycle amplitude by a factor of two from Western Europe towards the Ural mountains, which decreases again towards the most eastern site, Zotino. These data reflect a strong influence of carbon exchange fluxes with the continental biosphere. In particular, during autumn and winter $\delta^{18} \mathrm{O}-\mathrm{CO}_{2}$ shows a decrease by more than $0.5 \%$ from Orléans (Western Europe) to Syktyvkar (Ural mountains) and Zotino (West Siberia), mainly caused by soil respiration fluxes depleted in $\delta^{18} \mathrm{O}$ with respect to atmospheric $\mathrm{CO}_{2} . \mathrm{CH}_{4}$ mixing ratios in the free troposphere at $3000 \mathrm{~m}$ over Western Siberia are higher by about $20-30 \mathrm{ppb}$ if compared to Western Europe. Wetland emissions seem to be particularly visible in July-September, with largest signals at Zotino in 1998. Annual mean $\mathrm{CH}_{4}$ mixing ratios decrease slightly from 1998 to 1999 at all Russian sites. In contrast to $\mathrm{CO}_{2}$ and $\mathrm{CH}_{4}$, which show significant vertical gradients between 2000 and $3000 \mathrm{~m}$ a.s.l., $\mathrm{N}_{2} \mathrm{O}$ mixing ratios are vertically very homogeneous and show no significant logitudinal gradient between the Ural mountains and Western Siberia, indicating insignificant emissions of this trace gas from boreal forest ecosystems in Western Siberia. The growth rate of $\mathrm{N}_{2} \mathrm{O}\left(1.2-1.3 \mathrm{ppb} \mathrm{yr}^{-1}\right)$ and the seasonal amplitude $(0.5-1.1 \mathrm{ppb})$ are similar at both aircraft sites, Syktyvkar and Zotino. For $\mathrm{SF}_{6}$ an annual increase of $5 \%$ is observed, together with a small seasonal cycle which is in phase with the $\mathrm{N}_{2} \mathrm{O}$ cycle, indicating that the seasonality of both trace gases are most probably caused by atmospheric transport processes with a possible contribution from stratosphere-troposphere exchange.
\end{abstract}

\footnotetext{
* Corresponding author.

e-mail: ingeborg.levin@iup.uni-heidelberg.de
} 


\section{Introduction}

The inexorable rise of $\mathrm{CO}_{2}$ in the atmosphere primarily reflects anthropogenic emissions from fossil fuel and land use changes. The annual average rate of atmospheric $\mathrm{CO}_{2}$ increase is, however, less than half the anthropogenic emissions, which implies that sinks, probably both in the oceans and on land, currently absorb the other fraction. More than 10 years ago, Keeling et al. (1989), in a modelling study based on observed latitudinal gradients of $\mathrm{CO}_{2}$ and ${ }^{13} \mathrm{CO}_{2}$, located a large fraction of these sinks in the northern hemisphere, mainly in the North Atlantic ocean, while Tans et al. (1990), in a study based on sea-to-air fluxes inferred from the $\mathrm{CO}_{2}$ saturation state of surface sea waters and on the latitudinal distribution of atmospheric $\mathrm{CO}_{2}$, pointed out that a significant sink of carbon must be attributed to the Northern Hemisphere continental biosphere. Since then, atmospheric studies (Fan et al., 1998; Bousquet et al., 1999; Kaminski et al., 1999; Rayner et al., 1999) and ecological measurements (Valentini et al., 2000) tend to support this latter finding by Tans et al. (1990), but the partitioning of the northern land sink between longitudes is still a point of debate.

In the last decade, the global network of atmospheric stations significantly increased at mid to high northern latitudes. However, most of the new stations are located in the marine boundary layer, or on the fringe of continents. As a consequence, the land fluxes remain poorly constrained. Although the atmospheric transport is a superb integrator of the surface fluxes, it is nevertheless difficult to make measurements in the continental atmosphere that are representative of large-scale sources and sinks, say at the regional to continental scale $\left(>10^{6} \mathrm{~km}^{2}\right)$. This is because the sources are spatially heterogeneous and highly variable in time, and because the atmospheric transport is also more variable over vegetated areas than over the oceans (Denning et al., 1996). Therefore, studies aiming to deduce the fluxes from atmospheric measurements are primarily limited by the lack of adequate data. It has been hypothesised (Tans et al., 1996) and further quantified (Gloor et al., 2000) that repeated vertical profiles in the middle of continents will improve the diagnostic power for quantifying the land carbon fluxes.

Our knowledge of the atmospheric $\mathrm{CO}_{2}$ distri- bution over the extended land masses of European Russia and Siberia is still very limited. Up to date, only one systematic study of vertical aircraft profiling over the Eurasian continent extending from Moscow to Yakutsk was reported by Nakazawa and co-workers (1997a). They made regular observations of $\mathrm{CO}_{2}$ and its stable isotope ratios as well as $\mathrm{CO}, \mathrm{CH}_{4}$ and $\mathrm{N}_{2} \mathrm{O}$; however, these were limited to the summer periods of 1992, 1993 and 1994. Within the European project EuroSiberian CarbonFlux three new sites for regular aircraft sampling over Russia have been established: Fyodorovskoye, Syktyvkar and Zotino. Together with new data from a parallel aircraft program over Western Europe, at Orléans, these measurements provide important new information on the trace gas climatology over the Eurasian continent from about $1^{\circ} \mathrm{E}$ to $89^{\circ} \mathrm{E}$ in the latitude belt of $48^{\circ} \mathrm{N}$ to $62^{\circ} \mathrm{N}$. In this paper, only the results from flask sampling at and above $2000 \mathrm{~m}$ a.s.l. are discussed. Also, we will only compare the measurements of greenhouse gases, i.e. $\mathrm{CO}_{2}$ concentration and stable isotope ratios in $\mathrm{CO}_{2}$ as well as $\mathrm{CH}_{4}$, $\mathrm{N}_{2} \mathrm{O}$ and $\mathrm{SF}_{6}$ mixing ratios. For more information on the complete set of trace substances and vertical profiles measured at these sites, see detailed reports by Lloyd et al. (2002), Ramonet et al. (2002a), and Sidorov et al. (2002).

\section{Sampling sites and methods}

\subsection{Flight locations}

Figure 1 shows the map of the EuroSiberian study region with the sampling locations. Extending from Western Europe to the Siberian Highlands, the four sampling sites represent considerably different catchment areas which are illustrated by trajectories that extend three days backwards in time starting from the stations at a height of $2500 \mathrm{~m}$ a.s.l. The back-trajectories are calculated with the Hybrid Single-Particle Lagrangian Integrated Trajectory (HYSPLIT4) model of Draxler and Hess (1997) using wind fields from the National Center for Environmental Prediction/National Oceanic and Atmospheric Administration (NCEP/NOAA) medium-range weather forecast model. While the Orléans site largely experiences North Atlantic air masses, the Fyodorovskoye and Syktyvkar sites, although still generally influenced by westerly winds, during 


\section{Orléans}

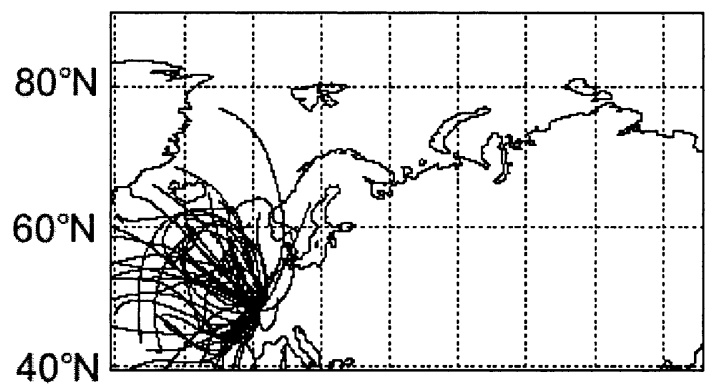

Syktyvkar

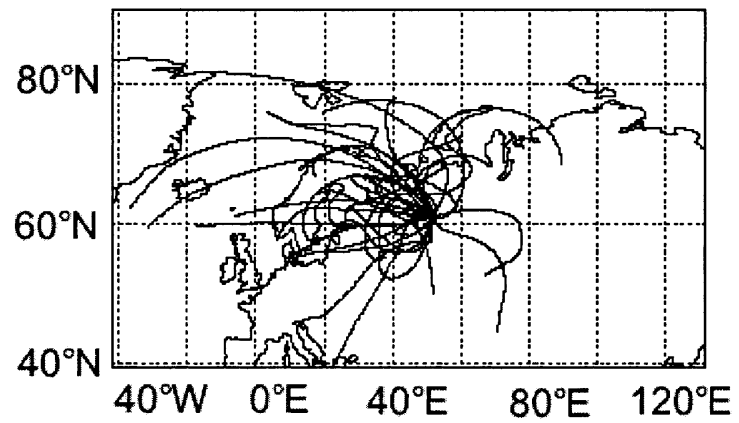

Fyodorovskoye

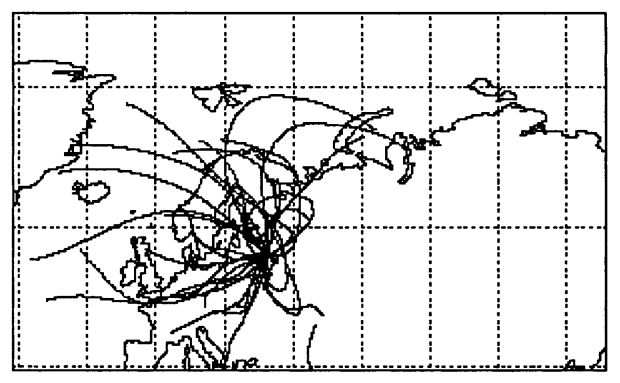

Zotino

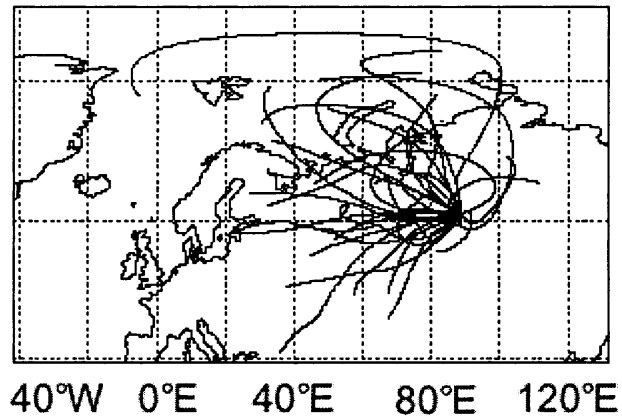

Fig. 1. Map of Eurasia with the sampling sites for vertical aircraft soundings and $3 \mathrm{~d}$ back trajectories calculated for the height level of $2500 \mathrm{~m}$ a.s.l. for the individual sampling dates and sites at Orléans, Fyodorovskoye, Syktyvkar and Zotino.

aircraft sampling are more influenced by north western air masses which spent considerable periods of time over north eastern Europe and Scandinavia. By contrast, the most continental Zotino sampling site on the margin of the west wind belt also occasionally observes air masses from north eastern Siberia and from the high Arctic.

The Orléans aircraft program is operated by the Laboratoire des Sciences du Climat et de l'Environnement, CE Saclay (LSCE), in cooperation with Meteo France since 1996. The flight location is at $1^{\circ} \mathrm{E}, 48^{\circ} \mathrm{N}$, about $300 \mathrm{~km}$ south of Paris over an area of agricultural land and forests. Regular vertical aircraft profiles for flask sampling are performed every $2-3 \mathrm{wk}$ from 100 to $3000 \mathrm{~m}$ a.s.l. Flasks are analysed at LSCE for $\mathrm{CO}_{2}$ concentration and stable isotope ratios $\left({ }^{13} \mathrm{C} /{ }^{12} \mathrm{C}\right.$ and ${ }^{18} \mathrm{O} /{ }^{16} \mathrm{O}$ ) in $\mathrm{CO}_{2}$, as well as for $\mathrm{CO}$ and $\mathrm{CH}_{4}$ mixing ratios.

The Fyodorovskoye aircraft program is oper- ated by the Svertsov Institute for Evolutionary and Ecological Problems (IPEE) in close cooperation with Max-Planck-Institut für Biogeochemie (MPI-BGC). The flight location for Fyodorovskoye is at $33^{\circ} \mathrm{E}, 56^{\circ} \mathrm{N}$ about $300 \mathrm{~km}$ north-west of Moscow. Vertical profiles of continuous $\mathrm{CO}_{2}$ NDIR, temperature and relative humidity measurements as well as flask sampling from 100 to $3000 \mathrm{~m}$ are performed every $2-4 \mathrm{wk}$. The sampling location is over the Central Forest Reserve at Fyodorovskoye in Central European Russia, the southern taiga, where continuous ground measurement sites in a forest and a bog have been established within EuroSiberian CarbonFlux (Schulze et al., 2002). Flask samples have been analysed by LSCE for $\mathrm{CO}_{2}$ concentration and stable isotope ratios in $\mathrm{CO}_{2}$, as well as for $\mathrm{CO}$ and $\mathrm{CH}_{4}$ mixing ratios. Due to several logistical and sampling problems, the records at this site contain large gaps, and complete seasonal cycles of trace gases from flask sampling are not 
yet available. For this first summary of the climatology of greenhouse gases over the EuroSiberian region, we will only compare individual $3000 \mathrm{~m}$ profile data points from Fyodorovskoye with the other aircraft data. A more detailed report summarising results from flasks and in situ profile measurements is given by Ramonet et al. (2002a).

The Syktyvkar aircraft program is operated by IPEE in close cooperation with MPI-BGC. Flights are performed $400 \mathrm{~km}$ west of the Ural mountains over the Vychegodsko-Mezenskoj plain, about $100 \mathrm{~km}$ south east $\left(52^{\circ} \mathrm{E}, 61^{\circ} \mathrm{N}\right)$ of the city of Syktyvkar (160000 inhabitants), the capital of the Republic of Komi. The area belongs to the northern European taiga, dominating vegetation in this area is pine forest (Pinus sylvestris). Vertical profiles of continuous $\mathrm{CO}_{2}$ NDIR soundings as well as temperature and relative humidity are measured every 2-4 wk. Duplicate flasks are collected here only at 2000, 2500 and $3000 \mathrm{~m}$ a.s.l. Flask samples have been analysed by the Institut für Umweltphysik, Universität Heidelberg (UHEIIUP) for $\mathrm{CO}_{2}$ concentration and stable isotope ratios in $\mathrm{CO}_{2}$, as well as for $\mathrm{CH}_{4}, \mathrm{~N}_{2} \mathrm{O}$ and $\mathrm{SF}_{6}$ mixing ratios.

The Zotino aircraft program is operated by the Institute of Forest, Siberian Branch, Russian Academy of Sciences (IF SB RAS) and MPI-BGC. The flight location for Zotino is at $89^{\circ} \mathrm{E}, 61^{\circ} \mathrm{N}$, about $600 \mathrm{~km}$ north of the city of Krasnoyarsk close to the small village Zotino located on the west bank of the Yenisei river. It is situated at the eastern edge of the West Siberian Lowland, an extended $\left(3 \times 10^{6} \mathrm{~km}^{2}\right)$ poorly drained area covered by $55 \%$ bogs and about $40 \%$ forests (Schulze et al., 2002). The whole region belongs to the Siberian taiga (boreal coniferous forest). Vertical profiles of $\mathrm{CO}_{2}$, measured with continuous NDIR, temperature and relative humidity, are obtained every $2-4 \mathrm{wk}$, and air samples are collected in glass flasks between 100 and $3000 \mathrm{~m}$ a.s.l. Flask samples collected between June 1998 and July 2000 have been analysed by CSIRO Atmospheric Research (CAR) for $\mathrm{CO}_{2}$ concentration and stable isotope ratios in $\mathrm{CO}_{2}$, as well as for $\mathrm{CO}, \mathrm{CH}_{4}, \mathrm{~N}_{2} \mathrm{O}$ and $\mathrm{H}_{2}$ mixing ratios. Flask samples collected from July 2000 onwards were analysed by MPI-BGC in a newly commissioned facility.

\subsection{Flask sampling}

At the Orléans site, vertical profiling for flask sampling was performed with light aircraft Piper
ARROW up to June 1999 and Piper AZTEC from Meteo France afterwards, whereas at the Russian sites, local Antonov-AN2 bi-plane aircraft were used. Separate air intake lines $(6 \mathrm{~mm}$ dekabon tubing) for continuous NDIR $\mathrm{CO}_{2}$ measurements (LiCor 6152) and for flask sampling systems were installed in the wings of the respective aircraft. Whole air samples were collected into pre-conditioned 1-L cylindrical flasks made of Pyrex glass with PFA O-ring valves (Glass Expansion, Australia) at both ends. Drying of the air was performed via magnesium perchlorate. Flasks were flushed for more than $5 \mathrm{~min}$ at a flow rate of ca. $4 \mathrm{~L} \mathrm{~min}{ }^{-1}$, and pressurised to 1 atmosphere above ambient pressure at final filling (pump: KNF-Neuberger, Germany, N86KNDC with EPDM membrane).

Drying of the air with magnesium perchlorate under conditions of changing pressure may influence the $\mathrm{CO}_{2}$ mixing ratio ending up in the flask. In our sampling system, the drying unit is located upstream of the pump unit, therewith experiencing only pressure changes according to the vertical atmospheric pressure change. Two different experiments have been performed to test possible systematic biases caused by the drying agent, one in the laboratory, simulating inlet pressure drops similar to those experienced during aircraft flights up to $8.5 \mathrm{~km}$ (Langenfelds et al., 1996), and two tests during real aircraft flights (Ramonet et al., 2002b). The laboratory tests resulted in no detectable changes associated to pressure changes while the tests performed during aircraft flights when comparing samples collected in parallel, with and without magnesium perchlorate showed differences between pairs of samples collected dry respectively wet of "dry-wet" $=-0.23 \pm 0.3$ $(n=4)$ during the first flight and of "dry-wet" $=-0.10 \pm 0.3 \quad(n=4)$ during the second flight. Within the standard deviation of this comparison, no significant offset could be observed. Any possible bias in the mixing ratios from aircraft samples reported here are thus probably smaller than $-0.25 \mathrm{ppm}$.

\subsection{Flask analysis}

Laboratories responsible for flask analysis were LSCE at Orléans and Fyodorovskoye, UHEIIUP at Syktyvkar and CAR and MPI-BGC at Zotino. At LSCE, $\mathrm{CO}_{2}$ concentration analysis was 
performed by NDIR (Hartmann \& Braun, Germany, URAS-3G), whereas at UHEI-IUP, CAR, and at MPI-BGC gas chromatographic (GC) systems with a nickel catalyst for conversion of $\mathrm{CO}_{2}$ into $\mathrm{CH}_{4}$, and flame ionisation detectors (FID) were used. Stable isotope ratios in $\mathrm{CO}_{2}$ were measured in all four laboratories by isotope ratio mass spectrometry (IRMS, Finnigan-252, Bremen, Germany), after cryogenic extraction of $\mathrm{CO}_{2}$ from the whole air samples. For description of the $\mathrm{CO}_{2}$ concentration and isotopic measurement procedures see Francey et al. (1996), Bourg and Ciais (1998, 1999), Neubert (1998), Ramonet et al. (1999), and Jordan and Brand (2001). In all laboratories, $\mathrm{CH}_{4}$ was analysed by GC-FID (Levin et al., 1999; Jordan and Brand, 2001; Langenfelds et al., 2001; Werner et al., 2001). The $\mathrm{N}_{2} \mathrm{O}$ mixing ratio was analysed by the GC electron capture detector technique (ECD) in all flasks from Syktyvkar and Zotino by UHEI-IUP, CAR and MPI-BGC (Jordan and Brand, 2001; Langenfelds et al., 2001; Schmidt et al., 2001). SF $_{6}$ was only measured in flasks from Syktyvkar by UHEI-IUP also using GC-ECD technique (Maiss et al., 1994).

\subsection{Calibrations and drift corrections}

For the $\mathrm{CO}_{2}$ mixing ratio, all data are reported in the $\mathrm{WMO} \mathrm{CO}_{2}$ mole fraction scale maintained at NOAA/CCGG, Boulder, CO, USA. Laboratory standards $\left(\mathrm{CO}_{2}\right.$ in natural air) were obtained from NOAA/CCGG. Stable isotope ratios in $\mathrm{CO}_{2}$ are reported on the Vienna-PDB- $\mathrm{CO}_{2}$ scale. Respective carbonate reference standard material (NBS-19) is provided by the International Atomic Energy Agency (IAEA), Vienna. These standards have to be chemically processed to yield carbon dioxide gas for calibration of the respective working gases (pure $\mathrm{CO}_{2}$ ) at the mass spectrometers. For $\delta^{18} \mathrm{O}$, calibration of the mass spectrometer can also be obtained through water standards (V-SMOW) which are equilibrated with $\mathrm{CO}_{2}$. The $\mathrm{V}-\mathrm{SMOW}$ scale is then mathematically converted to the V-PDB- $\mathrm{CO}_{2}$ scale. In this kind of calibration, chemical or physical processing of primary reference material is necessary for the transfer of the V-PDB (and the V-SMOW) scale to atmospheric $\mathrm{CO}_{2}$ samples. Through these processes, laboratory biases may be introduced which may cause systematic calibration errors of laborat- ory working standards (pure $\mathrm{CO}_{2}$ ) and finally to the whole-air standards used to check the extraction procedures in the individual laboratory. This is particularly true for $\delta^{18} \mathrm{O}$. However, whole-air standards such as those for $\mathrm{CO}_{2}$ mixing ratios are not yet available for stable isotope ratios in $\mathrm{CO}_{2}$; therefore, using carbonate or water standards transferred to $\mathrm{CO}_{2}$ is the only "absolute" way to provide calibration of isotope ratio measurements in atmospheric $\mathrm{CO}_{2}$. To date, MPI-BGC $\delta^{18} \mathrm{O}$ data are calibrated against a whole air standard using the value assigned to it by CAR. All isotope ratio data are corrected for interference with $\mathrm{N}_{2} \mathrm{O}$. The absolute calibration procedures used in the individual labarotories are reported in the detailed descriptions of the data from the individual sites (Lloyd et al., 2002; Ramonet et al., 2002a; Sidorov et al., 2002).

For $\mathrm{CH}_{4}$ all laboratories relate their mixing ratios to the NOAA/CCGG scale. For $\mathrm{N}_{2} \mathrm{O}$ no internationally agreed calibration scale is available. CAR and MPI-BGC relate their standards to the scale that is maintained at CAR and derived from a suite of mixtures gravimetrically prepared by NOAA/CMDL, while UHEI-IUP is preliminarily linked to the SIO93 scale maintained at Scripps Institution of Oceanography for the ALE/GAGE and AGAGE programs (Weiss et al., 1981; Schmidt et al., 2001). The scale factor linking these scales has been precisely determined through regular exchange by CAR and SIO of high-pressure cylinders used as calibration standards in the AGAGE program to 0.99252 , equivalent to a difference of $2.4 \mathrm{ppb}$ (CAR-SIO93) at a $\mathrm{N}_{2} \mathrm{O}$ mixing ratio of $315 \mathrm{ppb}$. The Zotino data presented here have been adjusted to the SIO93 scale. Preliminary results from a flask intercomparison between CAR and UHEI-IUP during the period 1998-2000 performed with stainless steel containers (2.5 L Sirocans, $n=16)$ and with glass flasks identical to those used in this program $(n=$ 10) showed a mean difference of 0.7 and $0.5 \mathrm{ppb}$, respectively, with UHEI-IUP data being higher. This not yet finally confirmed scale difference must be kept in mind when comparing Zotino and Syktyvkar $\mathrm{N}_{2} \mathrm{O}$ flask data. $\mathrm{SF}_{6}$ data from UHEIIUP are reported relative to a diluted gravimetric standard gas provided by Messer Griesheim, Mannheim, Germany. The dilution procedure is described by Maiss et al. (1996). Its absolute accuracy is better than $1 \%$. 
Based on long-term tests performed at CAR and MPI-BGC, all $\mathrm{CO}_{2}$ and $\mathrm{N}_{2} \mathrm{O}$ mixing ratios presented here have been corrected for drift during storage. Experiments were performed by "sausage filling" of multiple flasks from a high-pressure cylinder with precisely determined mixing ratios, to a pressure typical of field samples. These storage tests will be described in detail on the EuroSiberian CarbonFlux web site (http:// www.bgc-jena.mpg.de/ martin.heimann/eurosib/), a brief summary is presented here. At CAR, test flask samples were each analysed once only, at various times up to 7 months after collection, while at MPI-BGC the same samples were re-analysed on multiple occasions up to $1 \mathrm{yr}$ after collection. For $\mathrm{CO}_{2}$, both laboratories observed an initial offset of $-0.06 \mathrm{ppm}$, and a subsequent drift of $-0.0012 \mathrm{ppm}$ per day of storage. For $100 \mathrm{~d}$ of storage this corresponds to a total correction of $+0.18 \mathrm{ppm}$. For $\mathrm{N}_{2} \mathrm{O}$, ignoring any initial offset which was not as well resolved relative to experimental precision, at least in the CAR tests, drift rates of -0.0035 and -0.0033 ppb per day were observed by CAR and MPI-BGC, respectively. The CAR value has been used to correct all data presented here. No significant drifts were observed for $\mathrm{CH}_{4}$. Although the stable isotopes of $\mathrm{CO}_{2}$ were not included in these tests, their stability has been previously monitored by CAR in their $0.5 \mathrm{~L}$ glass flasks, fitted with the same types of taps and O-rings. No significant drifts were observed in $\delta^{13} \mathrm{C}$. No consistent drifts were observed in $\delta^{18} \mathrm{O}$ although in isolated cases, individual flasks did exhibit large drifts that were probably related to elevated moisture levels (see also Gemery et al., 1996).

\subsection{Laboratory intercomparison}

Besides relating our measurements of greenhouse gases to common international standards (where available), quality control and intercomparison of the individual laboratories participating in this joint project is crucial to achieve comparable and reliable results. Within the EuroSiberian CarbonFlux project, a number of intercomparison exercises have been performed: exchange of pure $\mathrm{CO}_{2}$ samples for isotopic analysis as well as exchange of high-pressure cylinders and flasks identically filled with tank air. In addition, intercomparison was performed through duplicate measurement of flask pairs by two different laboratories. All these intercomparison results are summarised by Levin et al. (2002). The mean differences and standard deviations for $\mathrm{CO}_{2}$ analyses between pairs of laboratories did not exceed $0.20 \pm 0.45 \mathrm{ppm}$ in $\mathrm{CO}_{2}$ mixing ratio, $0.06 \pm 0.03 \%$ o in $\delta^{13} \mathrm{C}$ and $0.15 \pm 0.17 \%$ in $\delta^{18} \mathrm{O}$ analyses. Nevertheless, these differences are large when considering the observed gradients between different sites, and need to be reduced in future work. Concerning $\mathrm{CH}_{4}$ concentration, the laboratories compare within their internal pair reproducibility, i.e. $\pm(2-5) \mathrm{ppb}$. For $\mathrm{N}_{2} \mathrm{O}$ the laboratories compare to better than $\pm 0.7 \mathrm{ppb}$. Special care was taken to assure the continuity of the record at the Zotino site when transferring the analysis from CAR to MPI-BGC. A total of 100 flasks was analysed in both laboratories with mean differences and standard deviations of individual comparisons (MPI-BGC-CAR) of $-0.11 \mathrm{ppm}$ $( \pm 0.15 \mathrm{ppm})$ for $\mathrm{CO}_{2}$ analyses, $0.03 \mathrm{ppb}$ $( \pm 1.94 \mathrm{ppb})$ for $\mathrm{CH}_{4}$ and $-0.09 \mathrm{ppb}( \pm 0.30 \mathrm{ppb})$ for $\mathrm{N}_{2} \mathrm{O}$.

\subsection{Data selection and typical pair reproducibility}

Except for the Fyodorovskoye sampling site, where serious contamination of the samples occurred from November 1998 until June 1999, the quality of the flask samples was good. Contamination of samples through leakage in the air intake line, which occurred at Fyodorovskoye but also at Syktyvkar during two flights in October 1999, was easily detected by extremely high $\mathrm{CO}_{2}$ and elevated $\mathrm{CH}_{4}$ mixing ratios. For all sites $\mathrm{CO}_{2}$ results with pair differences larger than $0.5 \mathrm{ppm}$ and $\delta^{13} \mathrm{C}-\mathrm{CO}_{2}$ differences larger than $0.1 \%$ have been rejected from the records. For the ${ }^{18} \mathrm{O} /{ }^{16} \mathrm{O}$ ratio of $\mathrm{CO}_{2}$, reliable drying of the samples is essential. On some occasions this was not achieved, and manifested itself in pair differences for $\delta^{18} \mathrm{O}$ larger than $0.15 \%$ o. These $\delta^{18} \mathrm{O}$ data have also been removed from the data sets. For the remaining samples, the mean pair reproducibility for the individual stations is given in Table 1 .

\subsection{Curve-fitting procedures}

To derive the amplitude and phase of the seasonal cycles as well as annual means for the different components at the different sites, har- 
Table 1. Pair reproducibility and its standard deviation for trace components analysed in aircraft flasks

\begin{tabular}{lcccc}
\hline & Orléans & Fyodorovskoye & Syktyvkar & Zotino \\
\hline $\mathrm{CO}_{2}(\mathrm{ppm})$ & $0.084 \pm 0.074$ & $0.10 \pm 0.08$ & $0.080 \pm 0.073$ & $0.10 \pm 0.09$ \\
$\delta^{13} \mathrm{C}-\mathrm{CO}_{2}(\%)$ & $0.012 \pm 0.012$ & $0.011 \pm 0.009$ & $0.008 \pm 0.008$ & $0.011 \pm 0.013$ \\
$\delta^{18} \mathrm{O}-\mathrm{CO}_{2}(\%)$ & $0.029 \pm 0.027$ & $0.024 \pm 0.21$ & $0.035 \pm 0.027$ & $0.033 \pm 0.026$ \\
$\mathrm{CH}_{4}(\mathrm{ppb})$ & $6.8 \pm 9.7$ & $4.5 \pm 4.3$ & $1.6 \pm 1.4$ & $1.1 \pm 0.9$ \\
$\mathrm{~N}_{2} \mathrm{O}(\mathrm{ppb})$ & - & - & $0.20 \pm 0.16$ & $0.11 \pm 0.10$ \\
$\mathrm{SF}_{6}(\mathrm{ppt})$ & - & - & $0.009 \pm 0.008$ & - \\
\hline
\end{tabular}

monic fit curves have been calculated through the data. Linear trends and seasonal cycles using two harmonics and digital filtering (cut-off period 6 months) have been calculated with a fitting routine from Nakazawa et al. (1997b). Due to occasional data gaps of several weeks up to months, annual mean values were calculated from the fitted harmonic curves and not from the data themselves. At all Russian stations except for Fyodorovskoye, complete annual cycles of observations exist only for 1999 and 2000; therefore, for these two years only mean values have been calculated and are compared in Section 3.3.

\section{Results}

\subsection{Carbon dioxide mixing ratios and ${ }^{13} \mathrm{C} /{ }^{12} \mathrm{C}$ ratio in atmospheric $\mathrm{CO}_{2}$}

Figures $2 \mathrm{a}-2 \mathrm{c}$ show the three year-long records of $\mathrm{CO}_{2}$ mixing ratio, $\delta^{13} \mathrm{C}-\mathrm{CO}_{2}$, and $\delta^{18} \mathrm{O}-\mathrm{CO}_{2}$ from the three aircraft sites Orléans, Syktyvkar, and Zotino. At all three sites, very regular seasonal cycles are observed at all three height levels and in all three components. At the two Russian sites, the $\mathrm{CO}_{2}$ and $\delta^{13} \mathrm{C}$ amplitudes decrease with height from 2000 to $3000 \mathrm{~m}$. As expected, the sign of $\mathrm{CO}_{2}$ and $\delta^{13} \mathrm{C}$ vertical gradients changes between summer, with a net ground level sink of $\mathrm{CO}_{2}$, and winter, with a net source. For Syktyvkar, in a number of profiles, the $\mathrm{CO}_{2}$ concentration gradient between 2000, 2500 and $3000 \mathrm{~m}$ was larger than $1 \mathrm{ppm}$, enough to derive with confidence the $\delta^{13} \mathrm{C}$ signature of the source $\mathrm{CO}_{2}$ and/or the discrimination of the sink responsible for this gradient. From a two-component mixing approach according to Keeling (1961) we calculated this source signature for individual profiles (Fig. 2b, lowest panel). The most depleted source signatures are observed during winter, possibly containing some contributions from fossil fuel emissions. The maximum summer sink $\delta^{13} \mathrm{C}$ signature of $-21 \pm 3 \%$ corresponds to an ecosystem discrimination $\Delta$ of $-13.5 \%$, assuming a mean summer CBL $\delta^{13} \mathrm{C}-\mathrm{CO}_{2}$ of $-7.5 \%$. Mean values of the apparent source signature for summer (June to October) are $-25.9 \pm 1.0 \%$ and for winter $-30.8 \pm 0.9 \%$. Similar seasonal differences of the apparent source signature in the order of $4-5 \%$ have been found at mid-northern latitude sites by Bakwin et al. (1995, 1998). Lloyd et al. (2002), inspecting vertical profiles at Zotino extending from 100 up to $3000 \mathrm{~m}$, also observed winter situations with source $\delta^{13} \mathrm{C}-\mathrm{CO}_{2}$ as depleted as $-31.6 \%$. These situations could be clearly identified as "polluted" by enhanced CO mixing ratios. Again during the winter season, however, they also frequently observed $\mathrm{CO}_{2}$ increases in the boundary layer which are not elevated in $\mathrm{CO}$, and therefore postulated to be caused by soil emissions of respiratory $\mathrm{CO}_{2}$ with source signatures ranging from $\delta^{13} \mathrm{C}=-26.8$ to $-28.9 \%$.

Figure 3 shows the correlation of de-trended $\delta^{13} \mathrm{C}$ and $1 /\left[\mathrm{CO}_{2}\right]$ at all four sites for free tropospheric air observed at the respective $3000 \mathrm{~m}$ height level for all data. The apparent source signatures change from Orléans with $\delta^{13} \mathrm{C}($ source $)=-24.8 \pm 1.4 \%$ to Fyodorovskoye with $\delta^{13} \mathrm{C}$ (source) $=-26.0 \pm 1.0 \%$, Syktyvkar with $\delta^{13} \mathrm{C}$ (source) $=-27.8 \pm 0.3 \%$, and Zotino with $\delta^{13} \mathrm{C}$ (source) $=-27.1 \pm 0.4 \%$. It is obvious from Fig. 3 that the scatter in the Keeling plots is larger at the two western sites Orléans and Fyodorovskoye than at the more continental stations. Except for occasional long-range transport of polluted air, the source distributions around Syktyvkar and Zotino are probably more homogeneous than further to the west, where sources from sea-to-air fluxes, natural ecosystems, agricultural land, and anthropogenic emissions all 

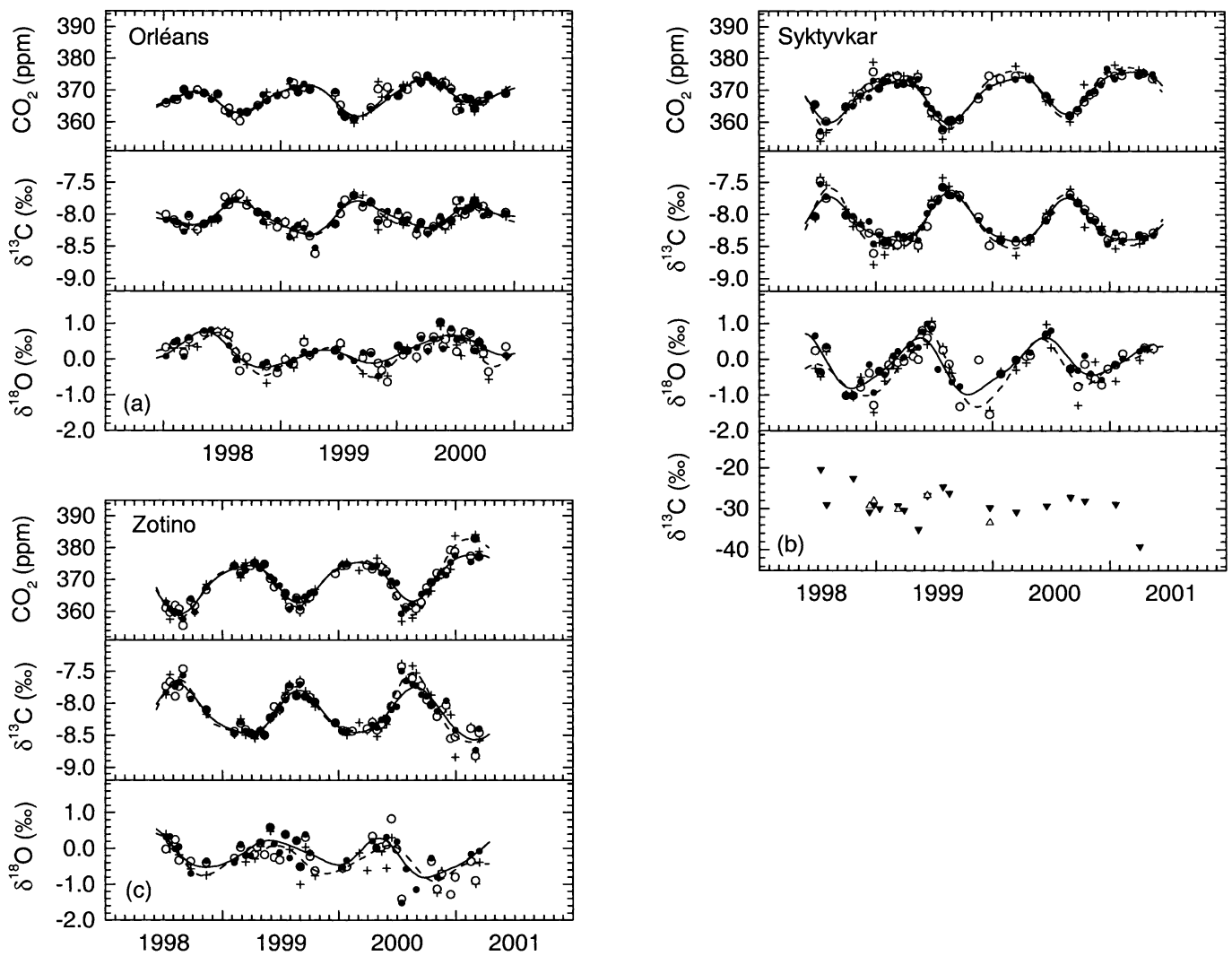

Fig. 2. (a) $\mathrm{CO}_{2}$ mixing ratio, $\delta^{13} \mathrm{C}-\mathrm{CO}_{2}$ and $\delta^{18} \mathrm{O}-\mathrm{CO}_{2}$ observed in aircraft samples over Orléans, France $\left(1^{\circ} \mathrm{E}\right.$, $48^{\circ} \mathrm{N}$ ) at three height levels, $2000 \mathrm{~m}$ (crosses), $2500 \mathrm{~m}$ (open circles) and $3000 \mathrm{~m}$ (closed circles). Dashed lines are harmonic fit curves through the $2000 \mathrm{~m}$ data, solid lines harmonic fit curves through the $3000 \mathrm{~m}$ data. (b) Same as (a) but for the Russian site Syktyvkar $\left(52^{\circ} \mathrm{E}, 61^{\circ} \mathrm{N}\right)$. The lowest panel shows apparent source signatures calculated from individual profiles where $\mathrm{CO}_{2}$ gradients between $3000 \mathrm{~m}$ and $2000 \mathrm{~m}$ (closed symbols) and $2500 \mathrm{~m}$ (open symbols) were larger than $1 \mathrm{ppm}$. (c) Same as (a) but for the Siberian site Zotino $\left(89^{\circ} \mathrm{E}, 61^{\circ} \mathrm{N}\right)$.

substantially contribute to the seasonality and variability. There is a slight gradient in the annual mean source signature along a transect from Orléans over Fyodorovskoye towards Syktyvkar and Zotino. Possibly, the presence of considerable areas of introduced $\mathrm{C} 4$ agricultural species such as maize and sorghum in Western Europe (Orléans) contribute to this gradient by reducing the overall extent of ${ }^{13} \mathrm{C}$ discrimination (Lloyd and Farquhar, 1994). The change of mean source signature in the order of -1 to $-2 \%$ observed between Fyodorovskoye and the two sites further to the north-east (Syktyvkar and Zotino) is, however, also consistent with the difference observed (and modelled) between temperate to cool and cold forest ecosystems by Kaplan et al. (2002).

\section{2. ${ }^{18} \mathrm{O} /{ }^{16} \mathrm{O}$ ratio in atmospheric $\mathrm{CO}_{2}$}

The $\delta^{18} \mathrm{O}-\mathrm{CO}_{2}$ records at all three sites (Figs. 2 and 4) also show a regular seasonality, however with a phase shift of about two months compared to $\delta^{13} \mathrm{C}$, the $\delta^{18} \mathrm{O}$ maximum occurring earlier in the year (May/June instead of July/August). Most visible at Syktyvkar, this maximum coincides with the maximum draw-down rate of $\mathrm{CO}_{2}$ mixing ratio in the atmosphere, i.e. when the net uptake of $\mathrm{CO}_{2}$ by plant assimilation (NEP) reaches maximum values (Arneth et al., 2002; Milyukova et al., 2002). Therefore, this $\delta^{18} \mathrm{O}-\mathrm{CO}_{2}$ maximum is most probably caused by strong photosynthetic activity and exchange of ${ }^{18} \mathrm{O}$ with leaf water in the plants, which is generally enriched due to evapotranspir- 


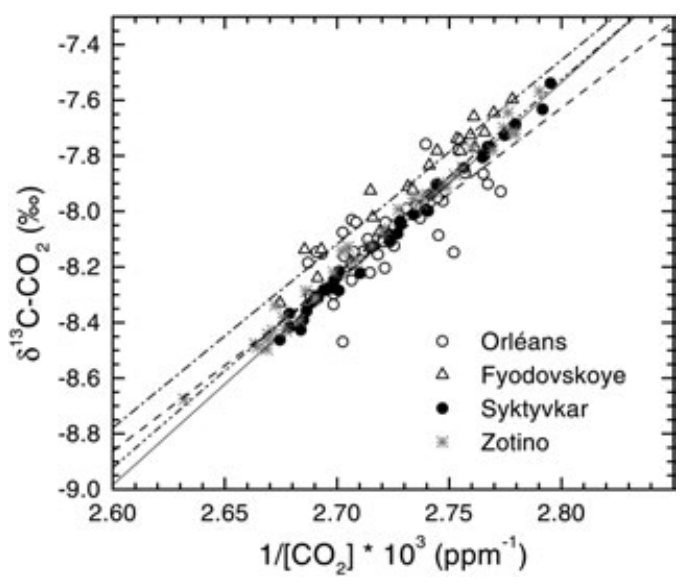

Fig. 3. "Keeling Plot" from detrended data normalised to 1999 of the inverse $\mathrm{CO}_{2}$ mixing ratios and $\delta^{13} \mathrm{C}-\mathrm{CO}_{2}$ to derive the mean $\delta^{13} \mathrm{C}$ source signatures driving the respective seasonal cycles at the four aircraft sites at $3000 \mathrm{~m}$ a.s.l. (Orléans: dashed line, $\delta^{13} \mathrm{C}_{\text {source }}=$ $-24.8 \pm 1.4 \%$; Fyodorovskoye: dotted-dashed line, $\delta^{13} \mathrm{C}_{\text {source }}=-26.0 \pm 1.0 \%$; Syktyvkar: solid line, $\delta^{13} \mathrm{C}_{\text {source }}=-27.8 \pm 0.3 \%$; $\quad$ Zotino: dashed-dot-dot line, $\delta^{13} \mathrm{C}_{\text {source }}=-27.1 \pm 0.4 \% 0$ ).

ation in $\delta^{18} \mathrm{O}-\mathrm{H}_{2} \mathrm{O}$ by about $10-20 \%$ if compared to the source (ground) water supply (Bariac et al., 1994; Langendörfer et al., 2002). The strong decrease in the atmospheric $\delta^{18} \mathrm{O}-\mathrm{CO}_{2}$ signal during the remaining summer and autumn season can be interpreted as a dominating influence of soil respiration $\mathrm{CO}_{2}$ fluxes over assimilation fluxes on the tropospheric $\delta^{18} \mathrm{O}-\mathrm{CO}_{2}$. Measurements in a Canadian boreal forest showed that $\mathrm{CO}_{2}$ originating from soil respiration is depleted in $\delta^{18} \mathrm{O}$ compared to atmospheric $\mathrm{CO}_{2}$ by about 5-20\%o (Flanagan et al., 1997), and, from aircraft sampling in the nocturnal boundary layer in early morning during the intensive campaign in Zotino, July 1998, a $\delta^{18} \mathrm{O}-\mathrm{CO}_{2}$ value for respired $\mathrm{CO}_{2}$ of $-15 \%$ has been obtained (Styles et al., 2002). At Syktyvkar and Zotino, throughout the year, $\delta^{18} \mathrm{O}$ seems to be slightly more depleted at the lower level $(2000 \mathrm{~m})$ than at $3000 \mathrm{~m}$, supporting the hypothesis of dominating influence from a generally depleted $\mathrm{CO}_{2}$ source and sink at ground level. This behaviour is less pronounced at Orléans than at the two Russian sites. Support for this also comes from the data presented by Lloyd et al. (2002). They observed that for the Zotino site, $\delta^{18} \mathrm{O}-\mathrm{CO}_{2}$ within the atmospheric boundary layer is always depleted with respect to the free troposphere, irrespective of whether the overall $\mathrm{CO}_{2}$ profile indicated the underlying terrestrial surface to be a source or a sink of $\mathrm{CO}_{2}$.

In autumn and early winter, most visible at Zotino in the second half of 2000, very depleted $\delta^{18} \mathrm{O}$ values are observed at the Russian sites. If these measurements are not affected by sampling or measurement problems, then the most plausible explanation is that they indicate strong ${ }^{18} \mathrm{O}$ equilibration processes (gross $\mathrm{CO}_{2}$ exchange) at ground surfaces rather than net $\mathrm{CO}_{2}$ emissions (i.e. from fossil fuels or net soil respiration).

\subsection{Comparison of $\mathrm{CO}_{2}$ and stable isotopic results between sites for free tropospheric conditions (3000 m a.s.l.)}

From examination of the continuous vertical profiles of $\mathrm{CO}_{2}$, relative humidity, and temperature, in most situations it is possible to determine the height of the atmospheric boundary layer (ABL) during individual flights (Lloyd et al., 2002; Ramonet et al., 2002a; Sidorov et al., 2002). Due to radiative/convective processes over the continents, this ABL height changes from $300-500 \mathrm{~m}$ during winter to $1500-2800 \mathrm{~m}$ in summer. Measurements within the ABL, even during the day, are still largely affected by regional shortterm ground level processes while, as a first-order approach, the $3000 \mathrm{~m}$ level represents the largescale background situation of the lower troposphere. Representative gradients over the EuroSiberian region can, therefore, be derived primarily from the data at the $3000 \mathrm{~m}$ level. For $\mathrm{CO}_{2}$ and its stable isotope ratios, Fig. 4 shows the comparison of observations at all four sites. (Note that for Fyodorovskoye harmonic fit curves have not been calculated due to data gaps.) The amplitudes of the seasonal cycles in all three components increase from Orléans towards Syktyvkar and Zotino (Table 2). The annual mean values show a significant increase in the $\mathrm{CO}_{2}$ mixing ratio and a corresponding decrease in $\delta^{13} \mathrm{C}-\mathrm{CO}_{2}$, from Syktyvkar towards Zotino in 1999, which indicates change of mean air mass origin and/or large net flux changes in the longitude band from Syktyvkar to Zotino, i.e. from about 50 to $90^{\circ} \mathrm{E}$, where large areas are covered by wetlands. The $\delta^{13} \mathrm{C}$ source signature of this flux is calculated to have a value of $-27.6 \%$, very similar to the source signature 


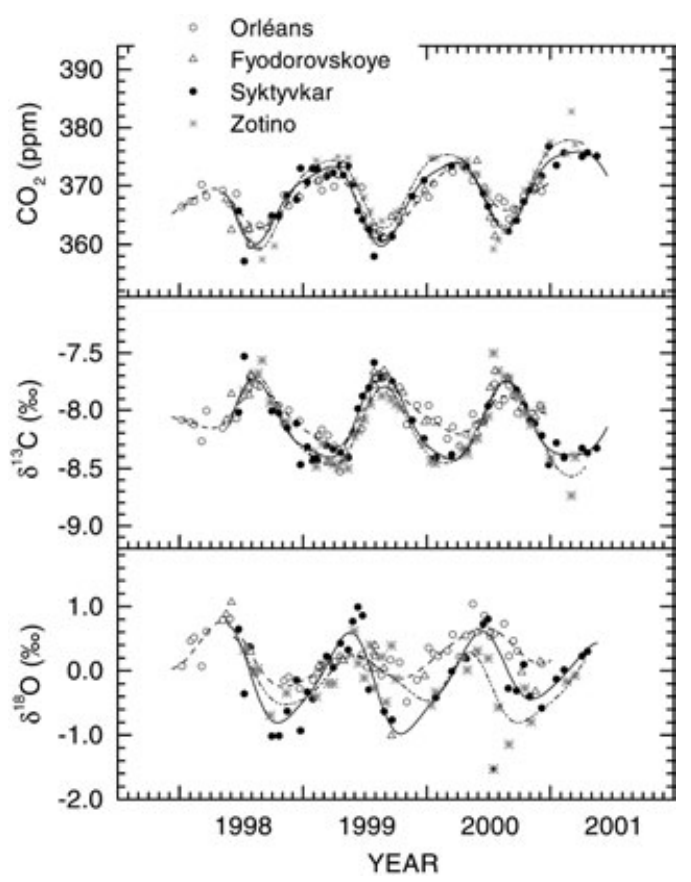

Fig. 4. Comparison of $\mathrm{CO}_{2}$ mixing ratio (upper panel), $\delta^{13} \mathrm{C}-\mathrm{CO}_{2}$ (middle panel) and $\delta^{18} \mathrm{O}-\mathrm{CO}_{2}$ (lower panel) at the four aircraft sites for the $3000 \mathrm{~m}$ level. The lines are harmonic fit curves through the respective data (Orléans: dashed line; Syktyvkar: solid line; Zotino: dashed-dot-dot line).

derived from the annual cycles at the two stations (Fig. 3). However, a positive gradient between Zotino and Syktyvkar of 1-2 ppm does not support the existence of strong ecosystem uptake, at least in Western and Central Siberia, as calculated by Bousquet et al. (1999).

One interesting feature of our observations is the $\delta^{18} \mathrm{O}-\mathrm{CO}_{2}$ gradient between Orléans and the two continental sites, Syktyvkar and Zotino, in autumn and winter of the order of -0.5 to $-1.0 \%$. A substantial gradient towards more continental longitudes within Eurasia, at least during times when the continents are a net source of $\mathrm{CO}_{2}$, was certainly expected from the well known gradient of $\delta^{18} \mathrm{O}$ in precipitation water (IAEA, 1969-1998; Sonntag et al., 1983). As a consequence of depleted precipitation, surface ground water has been modelled to show a decrease of the order of $10-20 \%$ between the Atlantic coast and the continental area around Syktyvkar and Zotino (Farquhar et al., 1993; Ciais et al., 1997; Cuntz et al., 2002). Our atmospheric $\delta^{18} \mathrm{O}-\mathrm{CO}_{2}$ observations, for the first time, manifest this gradient as being transferred through surface vegetation interaction into the isotopic abundance of atmospheric $\mathrm{CO}_{2}$ in the respective area.

From the observed signal we can roughly estimate the respiration flux that must be involved in this proces. We assume a mean residence time of air masses reaching central Eurasia to about $5 \mathrm{~d}$ (see trajectories in Fig. 1), and a well mixed lower tropospheric air mass layer $M$ of $3000 \mathrm{~m}$ thickness (our observation level) which is influenced by the surface flux. The change in $\delta^{18} \mathrm{O}-\mathrm{CO}_{2}$ $\left(\Delta \delta^{18} \mathrm{O}_{\text {air }} / \Delta t\right)$ between Orléans and central Eurasia is given by the mass balance equation:

$M \frac{\Delta \delta^{18} \mathrm{O}_{\text {air }}}{\Delta t}=A \Delta_{\text {leaves }}+R\left(\delta^{18} \mathrm{O}_{\text {soil }}-\delta^{18} \mathrm{O}_{\text {air }}-\varepsilon_{\text {soil }}\right)$

where $A$ and $R$ are the gross carbon fluxes of photosynthesis and ecosystem respiration, respectively, $\Delta_{\text {leaves }}$ is the leaf isotope discrimination and $\delta^{18} \mathrm{O}_{\text {soil }}$ and $\varepsilon_{\text {soil }}$, respectively, the isotopic composition of soil-respired $\mathrm{CO}_{2}$ and the diffusive soil-atmosphere fractionation [7.2\%o after Miller et al. (1999)]. Assuming $A$ to be zero in late autumn and early winter, and a $\delta^{18} \mathrm{O}_{\text {soil }}$ of $-12 \%$ from a global modelling study (Cuntz et al., 2002), we can estimate the respiration flux $R$ to $0.25 \mathrm{~mol}$ $\mathrm{CO}_{2} \mathrm{~m}^{-2} \mathrm{~d}^{-1}$ or $3 \mu \mathrm{mol} \mathrm{m} \mathrm{m}^{-2} \mathrm{~s}^{-1}$ during this time of the year. This value is in reasonable agreement with eddy flux measurements in the same region at that time of the year (Milyukova et al., 2002). However, this flux would, if the emitted $\mathrm{CO}_{2}$ remained in the mixing layer over $5 \mathrm{~d}$ (as was assumed for $\delta^{18} \mathrm{O}$ in our simple approach) cause a continental gradient in the order of $10 \mathrm{ppm}$. As we only observe a $\mathrm{CO}_{2}$ increase of less than $4 \mathrm{ppm}$ between Orléans and Zotino (associated with the $\delta^{18} \mathrm{O}$ gradient of $-0.5 \%$ ) our mass balance equation is probably too simple. Processes such as vertical mixing into the free troposphere (above $3000 \mathrm{~m}$ ) which reduce the concentration increase have to be considered; but also possible ${ }^{18} \mathrm{O}$ equilibration of atmospheric $\mathrm{CO}_{2}$ with soil surface water by invasion into the topsoil (Tans, 1998) may increase the $\delta^{18} \mathrm{O}$ gradient without altering the $\mathrm{CO}_{2}$ gradient. 
Table 2. Average peak-to-peak amplitudes (1998-2001) and annual mean values 1999 and 2000 of trace gas components measured at the EuroSiberian aircraft sites ${ }^{\mathrm{a}}$

\begin{tabular}{|c|c|c|c|}
\hline & Orléans & Syktyvkar & Zotino \\
\hline \multicolumn{4}{|l|}{$\mathrm{CO}_{2}(\mathrm{ppm})$} \\
\hline Peak-to-peak amplitude & $8.36(83,243)$ & $12.4(68,232)$ & $13.06(66,238)$ \\
\hline Annual mean 1999 & $367.16 \pm 0.61$ & $367.60 \pm 0.29$ & $369.66 \pm 0.39$ \\
\hline Annual mean 2000 & $369.59 \pm 0.37$ & $369.57 \pm 0.31$ & $370.61 \pm 0.56$ \\
\hline \multicolumn{4}{|l|}{$\delta^{13} \mathrm{C}(\%)$} \\
\hline Peak-to-peak amplitude & $0.36(237,86)$ & $0.67(230,60)$ & $0.67(239,74)$ \\
\hline Annual mean 1999 & $-8.062 \pm 0.035$ & $-8.112 \pm 0.017$ & $-8.184 \pm 0.017$ \\
\hline Annual mean 2000 & $-8.043 \pm 0.018$ & $-8.136 \pm 0.015$ & $-8.146 \pm 0.040$ \\
\hline \multicolumn{4}{|l|}{$\delta^{18} \mathrm{O}(\% 0)$} \\
\hline Peak-to-peak amplitude & $0.84(162,310)$ & $1.30(141,298)$ & $0.80(143,340)$ \\
\hline Annual mean 1999 & $-0.04 \pm 0.05$ & $-0.22 \pm 0.08$ & $-0.09 \pm 0.09$ \\
\hline Annual mean 2000 & $0.25 \pm 0.05$ & $-0.02 \pm 0.07$ & $-0.33 \pm 0.13$ \\
\hline \multicolumn{4}{|l|}{$\mathrm{CH}_{4}(\mathrm{ppb})$} \\
\hline Peak-to-peak amplitude & - & $17.0(32,244)$ & $33.9(43,192)$ \\
\hline Annual mean 1999 & - & $1815.4 \pm 1.3$ & $1826.9 \pm 3.1$ \\
\hline Annual mean 2000 & - & $1821.1 \pm 4.1$ & $1823.8 \pm 2.7$ \\
\hline \multicolumn{4}{|l|}{$\mathrm{N}_{2} \mathrm{O}(\mathrm{ppb})$} \\
\hline Peak-to-peak amplitude & - & $0.50(3,232)$ & $1.08(50,199)$ \\
\hline Annual mean 1999 & - & $314.23 \pm 0.09$ & $313.45 \pm 0.09$ \\
\hline Annual mean 2000 & - & $315.40 \pm 0.06$ & $314.76 \pm 0.04$ \\
\hline \multicolumn{4}{|l|}{$\mathrm{SF}_{6}(\mathrm{ppt})$} \\
\hline Peak-to-peak amplitude & - & $0.060(55,263)$ & - \\
\hline Annual mean 1999 & - & $4.499 \pm 0.005$ & - \\
\hline Annual mean 2000 & - & $4.719 \pm 0.007$ & - \\
\hline
\end{tabular}

a The numbers in parentheses are the respective Julian days of the seasonal cycle maximum and minimum.

\subsection{Methane mixing ratio}

Our main objective when starting this aircraft program was to investigate the carbon balance over Russia. Concerning gross carbon fluxes between the biosphere and the atmosphere, this exchange (to more than $98 \%$ ) is dominated by carbon dioxide. However, in the taiga and tundra regions of the West Siberian Lowland with its extended wetland areas, net carbon fluxes associated with anaerobic decomposition of organic material and eventual emissions of methane cannot be neglected. Estimated ranges of $\mathrm{CH}_{4}$ emissions from this area are between 10 and $30 \mathrm{Tg}$ $\mathrm{CH}_{4}$ per year $\left(0.007-0.022 \mathrm{PgC} \mathrm{yr}^{-1}\right)$, depending on the study (Aselmann and Crutzen, 1989; Bartlett and Harriss, 1993; Christensen et al., 1996). This corresponds to a carbon source to the atmosphere in the order of $10 \%$ of the absolute value of a postulated net $\mathrm{CO}_{2}$ uptake in the order of $0.1 \mathrm{PgC} \mathrm{yr}^{-1}$ by the biosphere in the same area (i.e. Bousquet et al., 1999). Moreover, with regard to the climatic impact of $\mathrm{CH}_{4}$, when using a time horizon of $100 \mathrm{yr}$, its global warming potential is higher by a factor of 21 compared to $\mathrm{CO}_{2}$ (IPCC, 1996). Thus, considering only the area of the West Siberian Lowland, the warming effect of its net $\mathrm{CH}_{4}$ emissions would still be about twice that of the potential "cooling" effect by the postulated $\mathrm{CO}_{2}$ sink!

Most of the flasks collected during aircraft profiling have been analysed for $\mathrm{CH}_{4}$ mixing ratio, with the results from the free tropospheric samples at $3000 \mathrm{~m}$ being presented in Fig. 5 (upper panel). As expected for mid-northern latitudes, the data from the Russian sites show a seasonality, with maximum concentrations during autumn and winter and a minimum in summer. However, particularly in 1998 the scatter of the data is rather 


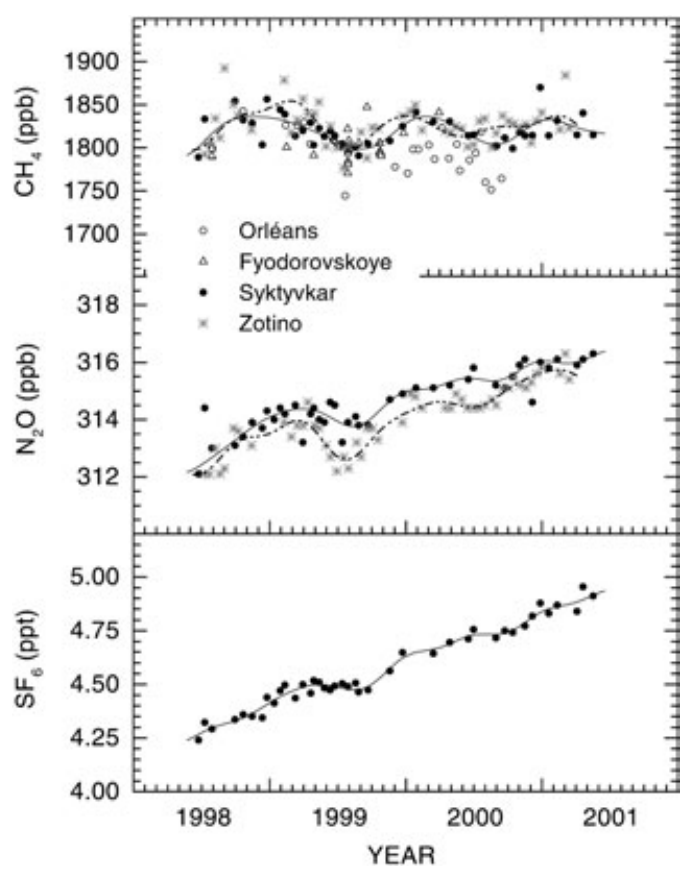

Fig. 5. Concentration records of the greenhouse gases $\mathrm{CH}_{4}$ (upper panel), $\mathrm{N}_{2} \mathrm{O}$ (middle panel) and $\mathrm{SF}_{6}$ (lowest panel) derived from aircraft samples at Orléans, Fyodorovskoye, Syktyvkar, and Zotino. The lines are harmonic fit curves through the Syktyvkar (solid line) and Zotino (dashed-dot-dot line) data. The $\mathrm{N}_{2} \mathrm{O}$ shift between Syktyvkar and Zotino is most probably due to different calibration scales used in the two laboratories.

large. A large variability of $\mathrm{CH}_{4}$ mixing ratios has been observed earlier by Tohjima et al. (1997) during transect flights over Siberia in July 1993. The seasonal peak-to-peak amplitudes at Syktyvkar and Zotino are up to $40 \mathrm{ppb}$ in 1998/1999. Due to occasionally high concentrations at Zotino, annual mean values are up to $10 \mathrm{ppb}$ higher at Zotino than at Syktyvkar during that period. Orléans data from Western Europe seem to be lower again by about $20-30 \mathrm{ppb}$. There is obviously a significant $\mathrm{CH}_{4}$ accumulation over Central Eurasia, most probably due to wetland emissions (late summer and autumn); however, influences from anthropogenic sources such as natural gas production and distribution cannot be excluded [a source of $17 \mathrm{Tg} \mathrm{CH}_{4} \mathrm{yr}^{-1}$ after Hein et al. (1997)]. Assuming a mean residence time of air masses of $3 \mathrm{~d}$ between Syktyvkar and Zotino, a $\mathrm{CH}_{4}$ gradient of $10 \mathrm{ppb}$, as observed in 1999 between the two sites, representing a well mixed air column up to $3000 \mathrm{~m}$, requires a methane source to the atmosphere of about $7 \mathrm{mg} \mathrm{CH}_{4}$ $\mathrm{m}^{-2} \mathrm{~d}^{-1}$. This flux may reflect emissions either from the widespread area of wetlands over the West Siberian Lowland or from large fields of natural gas exploited from the Northern $\mathrm{Ob}$ river basin. Our estimated emission is close to the mean summer season (June-October) methane flux density estimated for the Hudson Bay Lowlands in Northern Canada, which ranges from about $2 \mathrm{mg}$ $\mathrm{CH}_{4} \mathrm{~m}^{-2} \mathrm{~d}^{-1}$ in October to a maximum of $13 \mathrm{mg}$ $\mathrm{CH}_{4} \mathrm{~m}^{-2} \mathrm{~d}^{-1}$ in August (Worthy et al., 2000). Also remarkable is that $\mathrm{CH}_{4}$ mixing ratios measured during individual flights in autumn 1999 are much less scattered than in autumn 1998, where occasionally very high mixing ratios up to $1890 \mathrm{ppb}$ are observed at Zotino even at $3000 \mathrm{~m}$. This high scatter in 1998 is possibly due to higher regional wetland emissions in 1998 compared to 1999. Globally speaking, 1998 was the warmest year of the last century, and also in marine background air an anomalous growth rate was observed, particularly in high northern latitudes by Dlugokencky et al. (2001), which they partly attribute to anomalously high wetland emissions. Examination of long-term weather records for the town of Surgut, located near the centre of the West Siberian Lowland, suggests that this may have also been the case in the extensive wetlands of that region. The mean temperature for July 1998 was $21.4^{\circ} \mathrm{C}$, higher than any value recorded between 1885 and 1983 in the long-term database for Surgut of Razuvayev et al. (1993). The highest July average temperature previously reported (excluding 1984 to 1993 for which we do not have data available) was $20.8^{\circ} \mathrm{C}$ in 1886 . This compares to an average July temperature in Surgut (calculated using $1885-1983$ data) of $17.1^{\circ} \mathrm{C}$, and a July 1999 temperature of $18.1^{\circ} \mathrm{C}$.

\subsection{Sulfur hexafluoride mixing ratio}

Sulfur hexafluoride $\left(\mathrm{SF}_{6}\right)$ is a chemically very stable and purely anthropogenic greenhouse gas, which is industrially used mainly in electrical insulation and switching, and for degassing and purifying of molten reactive metals (Maiss and Brenninkmeijer, 1998). Destruction of $\mathrm{SF}_{6}$ occurs only in the very high stratosphere and in the 
mesosphere. Since the 1970s, atmospheric $\mathrm{SF}_{6}$ has been increasing globally at a rate of more than $6 \%$ per year (Maiss et al., 1996; Geller et al., 1997). $\mathrm{SF}_{6}$ mixing ratios have only been analysed in the Syktyvkar flasks (Fig. 5, lowest panel). As observed globally, this greenhouse gas is still strongly increasing at a recent rate of about $5 \%$ per year. $\mathrm{SF}_{6}$ shows a regular seasonality which is strikingly in parallel to $\mathrm{N}_{2} \mathrm{O}$ (Fig. 5, middle panel). This seasonal cycle must be associated with atmospheric transport patterns, as the purely anthropogenic sources of $\mathrm{SF}_{6}$ have no seasonality (see discussion in Section 3.6).

\subsection{Nitrous oxide mixing ratio}

Nitrous oxide $\left(\mathrm{N}_{2} \mathrm{O}\right)$ is a greenhouse gas with natural and anthropogenic sources (Ehhalt et al., 2001). Major emissions are from natural tropical soils as well as from the ocean. Fertilised soils are a large anthropogenic source in mid-northern latitudes as well as a number of industrial processes. $\mathrm{N}_{2} \mathrm{O}$ mixing ratios were determined in all flasks from Syktyvkar and Zotino. Figure 5 (middle panel) shows the results at both sites for the highest flight level. Both aircraft records show a pronounced seasonality with a peak-to-peak amplitude between 0.5 and $1.1 \mathrm{ppb}$. The mean growth rate is $1.2-1.3 \mathrm{ppb} \mathrm{yr}^{-1}$. The mean $\mathrm{N}_{2} \mathrm{O}$ level at Syktyvkar is higher than at Zotino by $0.7 \mathrm{ppb}$. This difference has the same magnitude as the preliminarily determined scale difference between CAR/MPI-BGC and UHEI-IUP of 0.5-0.7 ppb [Section 2.4 and Levin et al. (2002)]. Therefore, although still preliminary, we conclude that there is no significant $\mathrm{N}_{2} \mathrm{O}$ difference in the free troposphere between Syktyvkar and Zotino. The $\mathrm{N}_{2} \mathrm{O}$ results from the 2000 and $2500 \mathrm{~m}$ levels [not shown here but presented by Lloyd et al. (2002) and Sidorov et al. (2002)] do not differ from the free troposphere values which, in combination with the missing gradient between Syktyvkar and Zotino suggests that, contrary to fertilised soils and soils exposed to nitrogen deposition (Bouwman et al., 1995), natural soils in boreal regions are probably not a large source of $\mathrm{N}_{2} \mathrm{O}$.

As mentioned earlier, the phasing of the seasonal cycle of $\mathrm{N}_{2} \mathrm{O}$ is very similar to that of $\mathrm{SF}_{6}$. This suggests that similar processes may be the driving modulating force for the observed seasonal cycles of both gases. $\mathrm{SF}_{6}$ has no seasonally varying sources, while for $\mathrm{N}_{2} \mathrm{O}$, natural and anthropogenic emissions from soils were observed to be highest during spring and summer (Flessa et al., 1995; Schmidt et al., 2001). This should lead to maximum concentrations in the free troposphere in summer and autumn. By contrast, concentrations of $\mathrm{N}_{2} \mathrm{O}$ (and $\mathrm{SF}_{6}$ ) tend to be more or less constant or even decreasing during summer. Therefore, rather than being due to seasonally varying sources, the observed seasonality of both gases is more likely due to atmospheric mixing processes. One process possibly contributing to the seasonal cycles of both greenhouse gases is a seasonally varying stratosphere-troposphere exchange. $\mathrm{N}_{2} \mathrm{O}$ is destroyed by photolysis at wavelengths between 180 and $230 \mathrm{~nm}$ in the stratosphere, it has no known sinks in the troposphere (Ehhalt et al., 2001). Due to the photolytical sink process, a steep vertical gradient of $\mathrm{N}_{2} \mathrm{O}$ is observed in the stratosphere with mixing ratios decreasing to only $10 \%$ of the tropospheric value above $25 \mathrm{~km}$. Similarly, $\mathrm{SF}_{6}$ mixing ratios decrease with height by almost 50\% (Harnisch et al., 1998; Strunk et al., 2000). If the seasonal cycles of $\mathrm{N}_{2} \mathrm{O}$ and $\mathrm{SF}_{6}$ were both due to a springtime input of stratospheric air intrusions into the troposphere, the ratio between the driving stratospheretroposphere gradients and the amplitudes in the troposphere of both gases should be similar. The troposphere minus lower stratosphere (250-100 hPa) difference for $\mathrm{N}_{2} \mathrm{O}$ in high northern latitudes is about $40 \mathrm{ppb}$, while the respective gradient for $\mathrm{SF}_{6}$ is about $0.6 \mathrm{ppt}$ (Strunk et al., 2000). The observed peak-to-peak amplitudes of the seasonal cycles at Syktyvkar are $0.5 \pm 0.3 \mathrm{ppb}$ for $\mathrm{N}_{2} \mathrm{O}$ and $0.060 \pm 0.035 \mathrm{ppt}$ for $\mathrm{SF}_{6}$. From this we derive ratios between gradient and seasonal amplitude differing by a factor of about 6-7 between $\mathrm{N}_{2} \mathrm{O}$ and $\mathrm{SF}_{6}$. In fact, the seasonal amplitude of $\mathrm{SF}_{6}$ in the southern hemisphere, which was largely attributed by Levin and Hesshaimer (1996) to stratosphere-troposphere exchange, is only about $0.02 \mathrm{ppt}$, one third of that observed at Syktyvkar. Consequently, other processes must contribute to the seasonal cycle of $\mathrm{SF}_{6}$. One of these may be the seasonal change of the circulation pattern, but this process can only contribute to the seasonal cycle of a trace gas in mid-to-high latitudes if that gas also has a significant latitudinal gradient. This is only the case for $\mathrm{SF}_{6}$, which 
shows an increase of about $0.2 \mathrm{ppt}$ from $70^{\circ} \mathrm{N}$ to $50^{\circ} \mathrm{N}$ (Maiss et al., 1996). All in all, this suggests that the origin of the tropospheric seasonal cycle of $\mathrm{N}_{2} \mathrm{O}$ is still not readily explicable, but that stratosphere-troposphere exchange which shows the correct phasing (Appenzeller et al., 1996) may make a significant contribution to the observed seasonal pattern observed over Western Siberia.

\section{Conclusions}

The EuroSiberian aircraft program, started in 1998, has provided a unique set of trace gas observations over the Eurasian continent which will serve as an invaluable source of information to investigate quantitatively the associated biogeochemical cycles with these entities. From the first results presented here we can conclude that the observed gradients in $\mathrm{CO}_{2}$ and stable isotopic ratios in the vertical and across the Eurasian continent are small. As expected, the seasonal amplitudes of $\mathrm{CO}_{2}$ concentration and stable isotope ratios in $\mathrm{CO}_{2}$ increase towards more continental sites due to large seasonal $\mathrm{CO}_{2}$ exchange fluxes with the continental biosphere. However, the largest changes in amplitude are observed between Orléans (Western Europe) and Syktyvkar, while the further increase in amplitude between Syktyvkar and Zotino is not significant. Also, the mean $\mathrm{CO}_{2}$ concentration and isotope ratios gradients within the Eurasian continent, i.e. between Syktyvkar and Zotino, are very small. The same is true for $\mathrm{CH}_{4}$. Here, probably due to net emissions from wetlands and natural gas production, we observe the largest gradient between Western Europe and Russia. Although still preliminary, no horizontal $\mathrm{N}_{2} \mathrm{O}$ gradient is observed between Syktyvkar and Zotino. From this and from vertical profiles of $\mathrm{N}_{2} \mathrm{O}$ which show no gradient between 2000 and $3000 \mathrm{~m}$, we infer that the natural boreal forest areas are probably neither a significant source nor a sink of $\mathrm{N}_{2} \mathrm{O}$ to the atmosphere. $\mathrm{N}_{2} \mathrm{O}$ and $\mathrm{SF}_{6}$ show small seasonal cycles over Eurosiberia which must be associated to the transport pattern in the sub-polar atmosphere. To validate transport patterns of models (Denning et al., 1999), $\mathrm{SF}_{6}$ measurements along the west-east transect Orléans-Syktyvkar-Zotino would be highly desirable.

The observed small atmospheric signals make high demands on measurement accuracy, and, as in our case of a concerted program with several participating laboratories, on inter-laboratory comparability. In fact, the latter may be the limiting component of a cooperative network, if these data are to be used successfully in model inversion estimates to derive net Eurasian trace gas fluxes. On the other hand, the interannual variability of horizontal gradients is considerable and our 3-yr observations can only provide a snapshot of the long-term climatology over this extended continental area. Much longer observational records are definitely necessary to provide reliable answers to the urgent questions of the role of the great land masses of the Eurasian continent in global budgets of atmospheric greenhouse gases.

\section{Acknowledgements}

We thank all colleagues from the EuroSiberian CarbonFlux project who helped to make this exercise a successful one. In particular, we thank the pilots of the AN2 aircraft and from Meteo France, and also the personnel at ground level who helped with all the logistics, as well as the technical and scientific staff in the analysing laboratories. We are also grateful to Takakiyo Nakazawa for providing his fit routines. Besides being always open for discussions on our ${ }^{18} \mathrm{O}$ results, Uwe Langendörfer spent numerous hours in conditioning about 1000 glass flasks for trace gas sampling. Colin Allison, Armin Jordan and Willi Brand are kindly acknowledged for their esteemed input to the manuscript. Also we thank Pieter Tans who reviewed the manuscript for Tellus, for his constructive comments and suggestions for improvements. This project has been partly funded by the European commission under ENV4-CT-97-0491 and by the Max-PlanckGesellschaft, München, Germany. 


\section{REFERENCES}

Appenzeller, C., Holton, J. R. and Rosenlof, K. H. 1996 Seasonal variation of mass transport across the tropopause. J. Geophys. Res. 101, D10, 15,071-15,078.

Arneth, A., Kurbatova, J., Lloyd, J., Kolle, O., Shibistova, O., Vygodskaya, N. N. and Schulze, E.-D. 2002. Comparative ecosystem-atmosphere exchange of energy and mass in a European and a central Siberian bog II. Interseasonal and interannual variability of $\mathrm{CO}_{2}$ fluxes. Tellus $54 \mathrm{~B}$, this issue.

Aselmann, I. and Crutzen, P. J. 1989. Global distribution of natural freshwater wetlands and rice paddies, their net primary productivity, seasonality and possible methane emissions. J. Atmos. Chem. 8, 307-358.

Bakwin, P., Tans, P. P., Zhao, C., Ussler, W. and Quesnell, E. 1995. Measurements of carbon dioxide on a very tall tower. Tellus 47B, 535-549.

Bakwin, P., Tans, P. P., White, J. W. C. and Andres, R. J. 1998. Determination of the isotopic $\left({ }^{13} \mathrm{C} /{ }^{12} \mathrm{C}\right)$ discrimination by terrestrial biology from a global network of observations. Global Biogeochem. Cycles 12, $555-562$.

Bariac, T., Gonzales-Dunia, J., Katerji, N., Béthenod, O., Bertolini, J. M. and Mariotti, A. 1994. Variabilité spatialle de la composition isotopique de l'eau $\left({ }^{18} \mathrm{O},{ }^{2} \mathrm{H}\right)$ dans le continuum sol-plante-atmosphère: 2. Approche en conditions naturelles. Chem. Geol. (Isotope Geoscience Section) 115, 317-333.

Bartlett, K. B. and Harriss, R. C. 1993. Review and assessment of methane emissions from wetlands. Chemosphere 26, 261-320.

Bourg, C. and Ciais, P. 1998. Mesure haute précision par spectrométrie de masse des rapports isotopiques $\delta^{13} \mathrm{C}$ et $\delta^{18} \mathrm{O} d u$ dioxide de carbone. DSM-LSCE, CEA Saclay, Report number CEA-R-5796.

Bourg, C. and Ciais, P. 1999. Mesure automatisée de la concentration en $\mathrm{CO}_{2}$ d'air atmosphérique prélevé dans des flacons. DSM-LSCE, CEA Saclay, Report number CEA-R-5873.

Bousquet P., Ciais, P., Peylin, P., Ramonet, M. and Monfray, P. 1999. Inverse modelling of annual $\mathrm{CO}_{2}$ sources and sinks 1 . Methods and control inversion. J. Geophys. Res. 104, 26,161-26,178.

Bouwman, A. F., v.d. Hoek, K. W. and Olivier, J. G. J. 1995. Uncertainties in the global distribution of nitrous oxide. J. Geophys. Res. 100, 2785-2800.

Ciais, P., Denning, A. S., Tans, P. P., Berry, J. A., Randall, D. A., Collatz, G. J., Sellers, P. J., White, J. W. C., Trolier, M., Meijer, H. A. J., Francey, R. J., Monfray, P. and Heimann, M. 1997. A three-dimensional synthesis study of $\delta^{18} \mathrm{O}$ in atmospheric $\mathrm{CO}_{2}: 1$. Surface fluxes. J. Geophys. Res. 102, 5857-5872.

Christensen, T. R., Prentice, I. C., Kaplan, J., Haxeltine, A. and Sitch, S. 1996. Methane flux from northern wetlands and tundra, Tellus 48B, 652-661.

Cuntz, M., Ciais, P. and Hoffmann, G. 2002. Modelling the continental effect of oxygen isotopes over Eurasia. Tellus 54B, this issue.

Denning, A. S., Randall, D. A., Collatz, G. J. and Sellers, P. J. 1996. Simulations of terrestrial carbon metabolism and atmospheric $\mathrm{CO}_{2}$ in a general circulation model. Part 2: Simulated $\mathrm{CO}_{2}$ concentrations. Tellus 48B, 543-567.

Denning, A. S., Holzer, M., Gurney, K. R., Heimann, M., Law, R. M., Rayner, P. J., Fung, I. Y., Fan, S.-M., Taguchi, S., Friedlingstein, P., Balkanski, Y., Maiss, M. and Levin, I. 1999. Three-dimensional transport and concentration of $\mathrm{SF}_{6}$ : a model intercomparison study (TransCom 2). Tellus 51B, 266-297.

Dlugokencky, E. J., Walter, B. P., Masarie, K. A., Lang, P. M. and Kasischke, E. S. 2001. Measurements of an anomalous global methane increase during 1998. Geophys. Res. Lett. 28, No. 3, 499-502.

Draxler, R. R. and Hess, G. D. 1997. Description of the HYSPLIT4 modeling system. NOAA Tech. Mem., ERLARL-224.

Ehhalt, D., Prather, M., Dentener, F., Derwent, R., Dlugokencky, E., Holland, E., Isaksen, I., Katima, J., Kirchhoff, V., Matson, P., Midgley, P. and Wang, M. 2001. Atmospheric chemistry and greenhouse gases. In: Climate change 2001: the scientific basis (eds. Houghton, J. T. et al.). Cambridge University Press, Cambridge, UK.

Fan, S.-M., Gloor, M., Mahlman, J., Pacala, S., Sarmiento, J. L., Takahashi, T. and Tans, P. P. 1998. A large terrestrial sink in North Amercia implied by atmospheric and oceanic carbon dioxide data and models. Science 282, 442-446.

Farquhar, G. D., Lloyd, J., Taylor, J. A., Flanagan, L. B., Syvertsen, J. B., Hubick, K. T., Wong, S. and Ehleringer, J. R. 1993. Vegetation effects on the isotope composition of oxygen in atmospheric $\mathrm{CO}_{2}$. Nature 363, 439-443.

Flanagan, L. B., Brooks, J. R., Varney, G. T. and Ehleringer, F. R. 1997. Discrimination against $\mathrm{C}^{18} \mathrm{O}^{16} \mathrm{O}$ during photosynthesis and the oxygen isotope ratio of respired $\mathrm{CO}_{2}$ in boreal forest ecosystems. Global Biogeochem. Cycles 11, 83-98.

Flessa, H., Dörsch, P. and Beese, F. 1995. Seasonal variation of $\mathrm{N}_{2} \mathrm{O}$ and $\mathrm{CH}_{4}$ fluxes in differently managed arable soils in southern Germany. J. Geophys. Res. 100, 23,115-23,124.

Francey, R. J., Steele, L. P., Langenfelds, R. L., Lucarelli, M. P., Allison, C. E., Beardsmore, D. J., Coram, S. A., Derek, N., de Silva, F., Etheridge, D. M., Fraser, P. J., Henry, R., Turner, B. and Welch, E. D. 1996. Global Atmospheric Sampling Laboratory (GASLAB): supporting and extending the Cape Grim trace gas programs. In Baseline atmospheric program (Australia) 1993 (eds. R. J. Francey, A. L. Dick and N. Derek). Bureau of Meteorology and CSIRO Division of Atmospheric Research, Melbourne, Australia, 8-29. 
Geller, L. S., Elkins, J. W., Lobert, J. M., Clarke, A. D., Hurst, D. F., Butler, J. H. and Myers, R. C. 1997. Troposphoric $\mathrm{SF}_{6}$ : observed latitudinal distribution and trends, derived emissions and interhemispheric exchange time. Geophys. Res. Lett. 24, 675-678.

Gemery, P. A., Trolier, M. and White, J. W. C. 1996. Oxygen isotope exchange between carbon dioxide and water following atmospheric sampling using glass flasks. J. Geophys. Res. 101, 14415-14420.

Gloor, M., Fan, S.-M., Pacala, S. W. and Sarmiento, J. L. 2000. Optimal sampling of the atmosphere for purpose of inverse modelling: a model study. Global Biogeochem. Cycles 14, 407-428.

Harnisch, J., Bischof, W., Borchers, R., Fabian, P. and Maiss, M. 1998. A stratospheric excess of $\mathrm{CO}_{2}-$ due to tropical deep convection? Geophys. Res. Lett. 25, 63-66.

Hein, R., Crutzen, P. J. and Heimann, M. 1997. An inverse modelling approach to investigate the global atmospheric methane cycle. Global Biogeochem. Cycles 11, 43-76.

IAEA Environmental Isotope Data 1969-1998: World survey of isotope concentrations in precipitation. IAEA Techn. Rep. Series, IAEA, Vienna.

IPCC 1996. Climate Change 1995. The science of climate change (eds. J. T. Houghton, L. G. Meira-Filho, B. A Callander, N. Harris, A. Kattenberg and K. Maskell) Cambridge University Press, Cambridge, UK

Jordan, A. and Brand, W. A. 2002. Trace gas measurement and quality assurance at the MPI for Biogeochemistry. Proceedings of the 11th WMO/IAEA Meeting of Experts on $\mathrm{CO}_{2}$ and related tracer measurement techniques, Tokyo, September 25-28, 2001. WMO Report, in press.

Kaminski, T., Heimann, M. and Giering, R. 1999. A coarse grid three-dimensional global inverse model of the atmospheric transport. 2. Inversion of the transport of $\mathrm{CO}_{2}$ in the 1980s. J. Geophys. Res. 104, $18,555-18,581$

Kaplan, J. O., Prentice, I. C. and Buchmann, N. 2002. The stable carbon isotope composition of the terrestrial biosphere: modeling at scales from leaf to globe. Global Biogeochem. Cycles, in press.

Keeling, C. D. 1961. The concentration and isotopic abundances of atmospheric carbon dioxide in rural and marine air. Geochim. Cosmochim. Acta $\mathbf{2 4}$ 277-298.

Keeling, C. D., Piper, S. C. and Heimann, M. 1989. A three-dimensional model of atmospheric $\mathrm{CO}_{2}$ transport based on observed winds: 4 . Mean annual gradients and interannual variations. Geophys. Monogr. 55, 305-363.

Langendörfer, U., Cuntz, M., Ciais, P., Peylin, P., Bariac, T., Milyukova, I., Kolle, O., Naegler, T. and Levin, I. 2002. Modelling of biospheric $\mathrm{CO}_{2}$ gross fluxes via oxygen isotopes in a spruce forest canopy: a ${ }^{222} \mathrm{Rn}$-calibrated box model approach. Tellus 54B, this issue.

Langenfelds, R. L., Francey, R. J., Steele, L. P., Lucarelli,
M. P., Spencer, D. A., Coram, S. A. and Broadhurst, K. 1996. Flask sampling from Cape Grim overflights. In: Baseline Atmospheric Program (Australia) 1994/95 (eds. R. J. Francey, A. L. Dick and N. Derek). Bureau of Meteorology and CSIRO Division of Atmospheric Research, Melbourne, Australia, 111-117.

Langenfelds, R. L., Steele, L. P., Allison, C. E. and Francey, R. J. 2001. GASLAB Calibration Information, Internal Report, CSIRO, Division of Atmospheric Research, Aspendale, Australia.

Levin, I. and Hesshaimer, V. 1996. Refining of atmospheric transport model entries by the globally observed passiv tracer distributions of ${ }^{85}$ krypton and sulfur hexafluoride $\left(S_{6}\right)$. J. Geophys. Res. 101, $16,745-16,755$.

Levin, I., Glatzel-Mattheier, H., Marik, T., Cuntz, M., Schmidt, M. and Worthy, D. E. 1999. Verification of German methane emission inventories and their recent changes based on atmospheric observations. J. Geophys. Res. 104, 3447-3456.

Levin, I., Langendörfer, U., Schmidt, M., Ramonet, M., Bourg, C. Kazan, V. Ciais, P., Langenfelds, R., Allison, C., Francey, R., Jordan, A., Brand, W., Neubert, R., Meijer, H. and Holmén, K. 2002. EuroSiberian CarbonFlux - Intercomparison Report. Proceedings of the 11th WMO/IAEA Meeting of Experts on $\mathrm{CO}_{2}$ and related tracer measurement techniques, Tokyo, September 25-28, 2001. WMO-Report, in press.

Lloyd, J. and Farquhar, G. D. $1994 .{ }^{13} \mathrm{C}$ discrimination during $\mathrm{CO}_{2}$ assimilation by the terrestrial biosphere. Oecologia 99, 201-215.

Lloyd, J., Langenfelds, R. L., Francey, R. J., Gloor, M., Tchebakova, N. M., Zolothukhine, D., Brand, W. A., Werner, R. A., Jordan, A., Allison, C. A., Zrazhewske, V., Shibistova, O. and Schulze, E.-D. 2002. A trace gas climatology above Zotino, central Siberia. Tellus 54B, this issue.

Maiss, M. and Brenninkmeijer, C. A. M. 1998. Atmospheric $\mathrm{SF}_{6}$ : trends, sources and prospects. Environ. Sci. Technol. 32, 3077-3086.

Maiss, M., Ilmberger, J., Zenger, A. and Münnich, K. O. 1994. A SF 6 tracer study of horizontal mixing in Lake Constance. Aquatic Sci. 56, 307-328.

Maiss, M., Steele, L. P., Francey, R. J., Fraser, P. J., Langenfelds, R. L., Trivett, N. B. A. and Levin, I. 1996. Sulfur hexafluoride - a powerful new atmospheric tracer. Atmosph. Environ. 30, 1621-1629.

Miller, J. B., Yakir, D., White, J. W. C. and Tans, P. P. 1999. Measurement of ${ }^{18} \mathrm{O} /{ }^{16} \mathrm{O}$ in the soil-atmosphere $\mathrm{CO}_{2}$ flux. Global Biogeochem. Cycles 13, 761-774.

Milyukova, I., Kolle, O., Varlagin, A., Vygodskaya, N. N., Schulze, E.-D. and Lloyd, J. 2002. Carbon balance of a southern taiga spruce stand in European Russia. Tellus 54B, this issue.

Nakazawa, T., Sugawara, S., Inoue, G., Machida, T., Makshyutov, S. and Mukai, H. 1997a. Aircraft measurements of the concentration of $\mathrm{CO}_{2}, \mathrm{CH}_{4}, \mathrm{~N}_{2} \mathrm{O}$, and $\mathrm{CO}$ and the carbon and oyxgen isotopic ratios of $\mathrm{CO}_{2}$ 
in the troposphere over Russia. J. Geophys. Res. 102 3843-3859.

Nakazawa, T., Ishizawa, M., Higuchi, K. and Trivett, N. B. A. 1997b. Two curve fitting methods applied to $\mathrm{CO}_{2}$ flask data. Environ. Metrics, 8, 197-218.

Neubert, R. 1998. Measurement of stable isotopomers of atmospheric carbon dioxide. PhD Thesis, University of Heidelberg, Germany (in German).

Ramonet, M., Ciais, P., Bourg, C., Kazan, V., Picard, D., Biraud, S., Grall, M., Sarda, R., Chamaret, P. and Monfray, P. 1999. Technical report LSCE, France, Report WMO/GAW 132.

Ramonet, M., Ciais, P., Nepomnjashiy, I. L., Sidorov, K., Lloyd, J., Neubert, R., Picard, D., Kazan, V., Kolle, O., Langendörfer, U. and Schulze, E.-D. 2002a. Three years of aircraft $\mathrm{CO}_{2}$ and isotope measurements over Fyodorovskoye in European Russia. Tellus 54B, this issue.

Ramonet, M., Schmidt, M., Pepin, L., Picard, D., Valant, C. and Ciais, P. 2002b. Using $\mathrm{Mg}\left(\mathrm{C}_{1} \mathrm{O}_{4}\right)_{2}$ for airborne air sampling. http://www.aerocarb.cnrs-gif.fr/

Rayner, P. J., Enting, I. G., Francey, R. J. and Langenfelds, R. 1999. Reconstructing the recent carbon cycle from atmospheric $\mathrm{CO}_{2}, \delta^{13} \mathrm{C}$ and $\mathrm{O}_{2} / \mathrm{N}_{2}$ observations. Tellus 51B, 213-232.

Razuvayev, V. N., Apasova, E. G. and Martuganov, R. A. 1993. Daily temperature and precipitation data for 223 USSR stations. NDP-40, Carbon Dioxide Information Analysis Center, Oak Ridge National Laboratory, Oak Ridge TN, USA.

Schmidt, M., Glatzel-Mattheier, H., Sartorius, H., Worthy, D. E. and Levin, I. 2001. Western European $\mathrm{N}_{2} \mathrm{O}$ emissions - a top down approach based on atmospheric observations. J. Geophys. Res. 106, 5507-5516.

Schulze E.-D., Vygodskaya, N. N., Tschebakova, N., Czimczik, C. I., Kozlov, D., Lloyd, J., Mollicone, D., Myachkova, E., Sidorov, K., Varlagin, A. and Wirth, C. 2002. The Eurosiberian Transect: an introduction to the experimental region. Tellus $\mathbf{5 4 B}$, this issue.

Sidorov, K., Sogachev, A., Langendörfer, U., Lloyd, J., Nepomnjashiy, I. L., Vygodskaya, N. N., Schmidt, M and Levin, I. 2002. Seasonal variability of $\mathrm{CO}_{2}$ in the lower troposphere above the eastern European Taiga. Tellus 54B, this issue.
Sonntag, C., Münnich, K. O., Jacob, H. and Rozanski, K. 1983. Variations of deuterium and oxygen-18 in continental precipitation and groundwater, and their causes. In: Variations in global water budget (eds. A. Street-Perrott et al.). D. Reidel Publishing Co., 107-124.

Strunk, M., Engel, A., Schmidt, U., Volk, C. M., Wetter, T., Levin, I. and Glatzel-Mattheier, H. 2000. $\mathrm{CO}_{2}$ and $\mathrm{SF}_{6}$ as stratospheric age tracers: consistency and the effect of mesospheric $\mathrm{SF}_{6}$-loss. Geophys. Res. Lett. 27, 341-344.

Styles, J. M., Lloyd, J., Zoluthukine, D., Lawton, K. A., Tchebakova, N., Francey, R. J., Arneth, A., Salamkho, D., Kolle, O. and Schulze, E.-D. 2002. Estimates of regional surface $\mathrm{CO}_{2}$ exchange and carbon and oxygen isotope discrimination during photosynthesis from profiles in the atmospheric boundary layer. Tellus 54B, this issue.

Tans, P. P., Fung, I. Y. and Takahashi, T. 1990. Observational constraints on the global atmospheric $\mathrm{CO}_{2}$ budget. Science 247, 1431-1438.

Tans, P. P., Bakwin, P. S. and Guenther, D. W. 1996. A feasible global carbon cycle observing system: a plan to decipher today's carbon cycle based on observations. Global Change Biol. 2, 309-318.

Tans, P. P. 1998. Oxygen isotopic equilibrium between carbon dioxide and water in soils. Tellus 50B, 163-178.

Tohjima, Y., Wakita, H., Maksyutov, S., Machida, T., Inoue, G., Vinnichenko, N. and Khattatov, V. 1997. Distribution of tropospheric methane over Siberia in July 1993. J. Geophys. Res. 102, 25,371-25,382.

Valentini, R. and 29 others 2000. Respiration as the main determinant of carbon balance in European forests. Nature 404, 861-865.

Weiss, R. F., Keeling, C. D. and Craig, H. 1981. The determination of tropospheric nitrous oxide. J. Geophys. Res. 86, 7197-7202.

Werner, R. A., Rothe, M. and Brand, W. A. 2001. Extraction of $\mathrm{CO}_{2}$ from air samples for isotopic analysis and limits to ultra high precision $\delta^{18} \mathrm{O}$ determination in $\mathrm{CO}_{2}$ gas. Rapid Comm. Mass Spectrom. 15, 2152-2167. Worthy, D. E. J., Levin, I., Hopper, J. F. and Trivett, N. B. A. 2000. Evidence for a link between climate change and northern wetlands methane emissions. J. Geophys. Res. 105, 4031-4038. 